\title{
Malpractice Payouts and Malpractice Insurance: Evidence from Texas Closed Claims, 1990-2003*
}

\author{
Charles Silver $^{\mathrm{a}}$, Kathryn Zeiler ${ }^{\mathrm{b}}$, Bernard S. Black ${ }^{\mathrm{a}, \mathrm{c}}$, David A. Hyman ${ }^{\mathrm{d}}$ \\ and William M. Sage ${ }^{\mathrm{a}, \mathrm{e}}$ \\ ${ }^{a}$ School of Law, University of Texas at Austin, 727 E. Dean Keeton St., Austin, TX 78731, U.S.A. \\ E-mail: csilver@law.utexas.edu \\ ${ }^{\mathrm{b}}$ Georgetown University Law Center, 600 New Jersey Ave., NW, Washington, DC 20001, U.S.A. \\ ${ }^{\mathrm{c}}$ Red McCombs School of Business, University of Texas at Austin, 727 E. Dean Keeton St., Austin, TX \\ 78731, U.S.A. \\ ${ }^{\mathrm{d}}$ Colleges of Law and Medicine, University of Illinois at Urbana-Champaign, 504 East Pennsylvania \\ Avenue, Champaign, IL 61820 U.S.A. \\ ${ }^{\mathrm{e}}$ Vice-Provost for Health Affairs, University of Texas at Austin, 727 E. Dean Keeton St., Austin, TX 78731, \\ U.S.A.
}

Using medical malpractice claims with payments of $\$ 25,000$ or more that closed in Texas from 1990 to 2003, this study quantifies physicians' insurance limits and examines the connection between policy size and payments on claims. It finds that most physicians had less than $\$ 1$ million (nominal) in coverage, that real policy size declined, that settlements at the policy limits were common, that payment size was stable or falling, and that payments above the policy limits were rare. It also finds that physicians rarely made out-of-pocket payments, suggesting the policy limits often cap recoveries, and that the frequency of out-of-pocket payments declined as policy size increased. Results are presented separately for "perinatal physicians."

The Geneva Papers (2008) 33, 177-192. doi:10.1057/gpp.2008.3

Keywords: medical malpractice; policy limits; claims; liability insurance; payments; settlements

\section{Introduction}

Many physicians express the fear of being "one lawsuit away from financial disaster". 1 Reflecting this, the American Medical Association, state medical societies, and tort reformers have proposed legislation that would reduce physicians' exposure to malpractice liability. Whether the fear has much foundation is unclear. Some sources

\footnotetext{
* The authors thank James Forman, Kris Henning, Greg Klass, Russell Localio, John Mikhail, Nick Rosencranz, Stephen Salop, and David Vladeck for comments. Versions of this article were presented at the Boston University School of Law, the Georgetown University Law Center, New York University School of Law, the Northwestern University Law School, the University of Chicago Law School, the University of Michigan Law School, and the University of Texas at Austin School of Law. We are grateful for comments received on these occasions. We owe special thanks to Vicky Knox at the Texas Department of Insurance and to JaeJoon Han, An-Shih Liu, and Rachel Miras-Wilson for research assistance. Funding for this study was provided by the Columbia Law School, the Georgetown University Law Center, the University of Illinois College of Law, and the University of Texas at Austin School of Law.

${ }^{1}$ See Jenkins (2003); Lowes (2003); Rice (2003).
} 
contend that insured physicians bear little personal exposure, ${ }^{2}$ even asserting the existence of "an unwritten rule among plaintiffs' attorneys to leave a physician's personal assets alone". ${ }^{3}$ Because insured physicians' out-of-pocket payments on malpractice claims have rarely been studied empirically, disagreement persists. ${ }^{4}$

Even less is known about physicians' insuring practices. Although the conventional wisdom is that most physicians purchase policies with $\$ 1$ million per occurrence limits, ${ }^{5}$ few studies test this belief, and those that do focus on dentists or anesthesiologists, rely on surveys, contain little or no data on policy size, or cover short time spans. ${ }^{6}$ Intuitively, one should expect physicians to buy different amounts of coverage, reflecting variations in states' tort regimes and financial responsibility requirements, malpractice risks associated with different specialties, costs, and tolerance for risk. ${ }^{7}$

Using a unique database maintained by the Texas Department of Insurance (TDI) of malpractice claims that closed with payments from 1990 to 2003, this study examines the insuring practices of Texas physicians and quantifies insured physicians' out-of-pocket payments. We find, first, that total payments at or near policy limits were common, especially when physicians had small policies or patients were newborns. Second, insured physicians rarely made out-of-pocket payments to resolve malpractice claims. This was true regardless of policy size, but doctors with larger policies used personal assets to resolve claims less often than others. Primary and excess carriers jointly contributed 99 percent of all dollars paid to claimants during our period of study. Third, only about one-third of primary policies had limits of $\$ 1$ million (nominal) or more, about the same percentage as had limits of $\$ 200,000$ (nominal) or less. Fourth, over time, nominal policy size was stable but real policy size fell substantially. ${ }^{8}$

\section{Methods}

\section{Data description}

TDI requires all malpractice carriers (including mutuals, reciprocal and interinsurance exchanges, pools, joint underwriting associations, and certain self-insurance mechanisms and trusts) to submit detailed reports on closed claims with payments by all defendants exceeding $\$ 25,000$ (nominal). Certain university hospitals with selffunded plans are not required to report. In 2005, TDI estimated that reporting entities covered 75 percent of licensed practicing Texas physicians.

\footnotetext{
${ }^{2}$ See Baker (2001); Rice (2006).

${ }^{3}$ Rice (2005).

${ }^{4}$ Lawthers et al. (1992).

${ }^{5}$ Cheney (1999); Quinn (1998).

${ }^{6}$ Lawthers et al. (1992); O'Hara et al. (1994); Milgrom et al. (1994); Conrad et al. (1995); Milgrom et al. (1995); Cheney (1999).

${ }^{7}$ American Medical Association (2005); General Accounting Office (2003).

${ }^{8}$ These findings are developed at greater length in Zeiler et al. (2007).
} 
Reports are available on claims closed 1988-2003, but we limit the data set to 1990-2003 because of under-reporting in prior years. ${ }^{9}$ To avoid inflation-induced changes in case mix over time caused by the reporting threshold, we exclude claims with payouts below $\$ 25,000$ in 1988 dollars. This eliminates 572 claims, 6 percent of the reports but only 1 percent of dollars paid. We also exclude claims against service providers other than physicians, claims for injuries caused other than by surgical or medical care, and claims covered by lines of insurance other than medical professional liability.

The data set contains separate reports for each defendant when multiple defendants made payments on the same claim. For example, a claim by a single patient paid by three physicians is reported as three separate claims in the data set. Our data set includes 9,525 reported payments made 1990-2003 relating to 8,400 distinct cases. We include all separate reports when analyzing policy limits and payments but exclude "duplicate" reports when discussing jury verdicts to avoid counting a single verdict more than once. We report all results in 2003 dollars ("2003\$") using the Bureau of Labor Statistics average consumer price index for changes in prices of all goods and services purchased for consumption by urban households, 2003 being the last year in our data set.

The "total payment" for a particular physician is the sum of the deductible, the primary carrier's payment, the excess carrier's payment, and the physician's out-ofpocket payment. The out-of-pocket payment is the physician's contribution reported as being an amount paid above the policy limit.

Malpractice policies contain "per occurrence" limits and aggregate annual limits. We used the policy's "per occurrence" limit to measure policy size when available (8,657 reports). Instead of reporting a "per occurrence" limit, carriers sometimes indicated a "combined single" limit. Following TDI's practice, we used this to measure policy size for 868 claims for which "per occurrence" limits were not reported. In robustness checks, we obtained similar results when we examined only claims with "per occurrence" limits.

Some physicians purchase excess policies to cover amounts in excess of primary policy limits. 136 reports include amounts paid by excess carriers. When comparing payouts to limits, we exclude these claims because we lack information on excess policy limits. 280 reports include amounts paid by physicians as deductibles. The mean (median) deductible was $\$ 39,000(\$ 25,000)(2003 \$)$. Deductibles of $\$ 100,000$ or more (2003\$) appear in 20 reports.

We lack data on physician specialty, but we have data on patient age when injured. We therefore use patient age to divide our sample into "perinatal physicians" (physicians whose claims involved patients aged $0-1$ month) and non-perinatal physicians (all others).

We also used the following data sources: for Texas population, U.S. Census Bureau; ${ }^{10}$ for number of Texas physicians, Texas Department of State Health

\footnotetext{
${ }^{9}$ For a discussion, see Black et al. (2005). Statistical tests found no evidence that reports filed in 1988-1989 are biased relative to reports filed in later years, and the main results reported here are robust to analyses including these years.

${ }^{10} \mathrm{http}: / /$ www.census.gov/popest/states/.
} 
Services; ${ }^{11}$ and for Texas personal health care expenditures, Centers for Medicare and Medicaid Services. ${ }^{12}$

\section{Legal environment}

Compensatory damages in medical malpractice cases in Texas were unlimited throughout the study period, except in cases involving death. In wrongful death cases, the sum of compensatory damages and prejudgment interest was capped at $\$ 500,000$ in 1977 dollars, adjusted for inflation (the 2003 cap was $\$ 1,540,000$ ). Punitive damages were also capped.

In 1995, Texas enacted a handful of tort reforms, including a stricter cap on punitive damages, changes in the applicability of contributory negligence to punitive damages, other contributory negligence reform, penalties for frivolous lawsuits, protection for Good Samaritans, joint and several liability reform, reform to arbitration rules in medical malpractice cases, general medical liability reform related to pretrial procedures and expert witness testimony, changes to burden of proof rules regarding punitive damages, statute of limitations for minors, and venue reform. ${ }^{13}$ In addition, punitive damages were capped at different amounts depending on whether a case was filed before September 1, 1995. These reforms may have reduced physicians' malpractice exposure.

\section{Statistical methods}

We performed all statistical analyses with STATA and Clarify. ${ }^{14}$ We performed diagnostic tests for all regressions using ordinary least squares (OLS) and used nonparametric tests when the diagnostics indicated that assumptions of the OLS model were not satisfied.

\section{Results}

\section{Payment-to-limit ratios}

To determine the relationship between claim payments and primary insurance limits, we computed payment-to-limit (PTL) ratios for the 9,389 cases with payments by primary insurers but not excess carriers. A $\$ 500,000$ payment on a $\$ 1$ million policy produces a PTL ratio of 0.5 . The ratio equals 1 when the payment equals the primary policy limit.

Figure 1 shows the distribution of PTL ratios for all claims and for claims involving perinatal physicians. The spikes at the policy limits are obvious and large. Sixteen percent of all claims, 32 percent of perinatal claims, and 14 percent of non-perinatal

\footnotetext{
${ }^{11}$ http://www.dshs.state.tx.us/chs/hprc/PHYS-lnk.shtm.

${ }^{12}$ http://www.cms.hhs.gov/NationalHealthExpendData/downloads/ nhestatesummary2004.pdf.

13 Avraham (2006).

${ }^{14}$ On STATA, see King et al. (2000). On CLARIFY, see Tomz et al. (2001).
} 

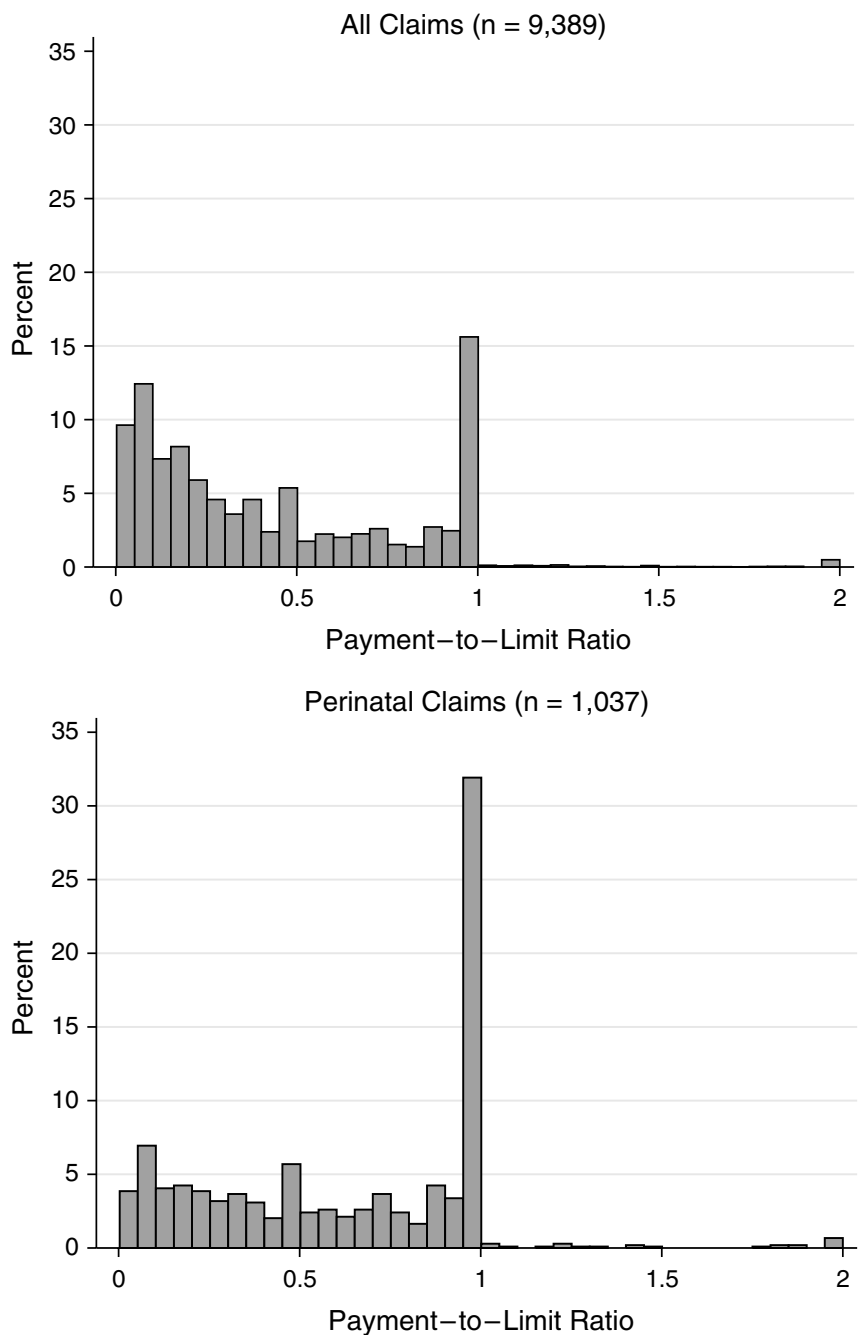

Figure 1. Distributions of payment-to-limit ratios: All claims $(n=9,389)$ and perinatal claims $(n=1,037)$. Distributions of payment-to-limit ratios for all claims and for perinatal claims against physicians covered by medical malpractice policies and closed from 1990 to 2003 with payout $>\$ 25,000$ in 1988 dollars, excluding claims with payments by excess carriers. Perinatal claims involved patients aged $0-1$ month. Each bar represents a 0.05 increment. All claims with ratios greater than 2 were set equal to 2 .

claims have ratios between 0.95 and 1 (inclusive); 14 percent of all claims, 29 percent of perinatal claims, and 12 percent of non-perinatal claims have ratios of exactly 1 . We obtain similar distributions using various subsets of the data (e.g., claims involving only single or only multiple physicians, claims involving brain damage or death) and across closing years. Because we lack data on eroded limits, which may be caused by payments on prior claims or defense costs, Figure 1 may understate the spike in payouts at available policy limits. 


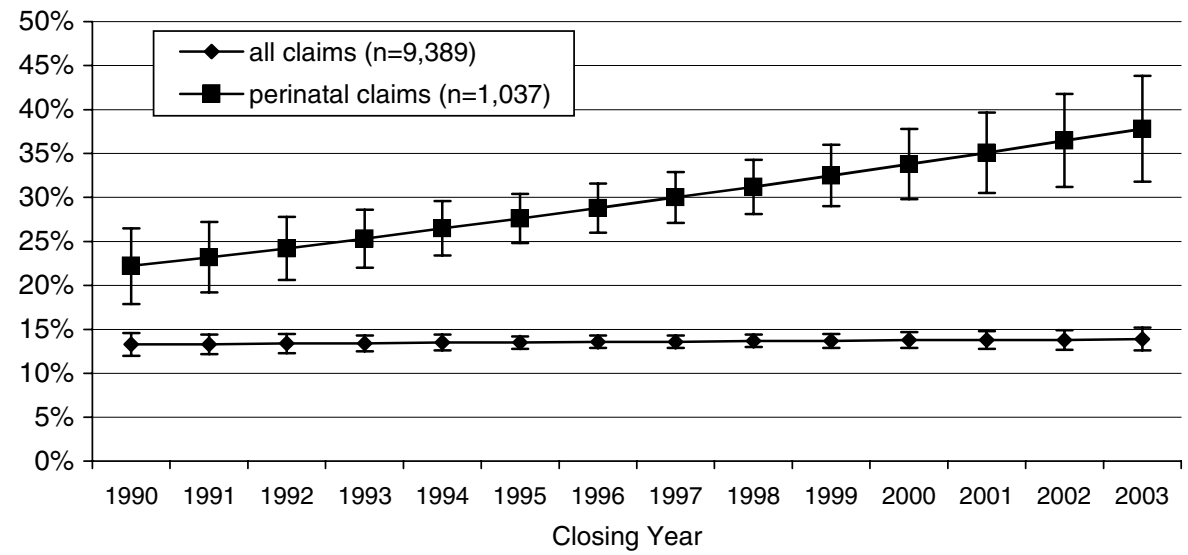

Figure 2. Predicted probabilities of a claim payment at the policy limit by year claim closed. Trends in predicted probabilities of a claim payment at the policy limits by closing years 1990-2003 for claims with payout $>\$ 25,000$ in 1988 dollars, excluding claims with payments by excess carriers. Perinatal claims involved patients aged 0-1 month. Error bars represent 95 percent confidence intervals.

Figure 2 displays trends in predicted probabilities of a claim payment made at the policy limit (PTL ratio equal to 1) across closing year. A logistic regression using all claims reveals no significant trend over time (odds ratio=1.00, 95 percent $\mathrm{CI}=[0.990,1.019])$. Using only perinatal claims, however, the same test reveals a statistically significant positive correlation between the likelihood of a claim payment made at the policy limit and closing year (odds ratio=1.06; 95 percent $\mathrm{CI}=[1.034,1.103])$.

The size of the at-limit spike is sensitive to the amount of insurance available to cover the claim. As Figure 3 shows, the spike is large when policy size is small, but shrinks as coverage increases. For claims covered by policies with limits less than or equal to $\$ 250,000$ (2003\$), 35 percent end up in the spike. Only 4 percent end up in the spike when limits are greater than $\$ 1$ million (2003\$).

\section{Payment sources}

Payments from sources other than primary insurers were rare. Ignoring deductibles (present in 263 cases without excess carrier payments), Table 1 shows that almost 98 percent of claims were resolved with primary carriers' money alone. Payments by primary carriers accounted for 96.8 percent of total dollars paid (2003\$), payments by excess carriers accounted for another 2.3 percent, and deductibles accounted for 0.4 percent. Physician out-of-pocket payments accounted for 0.5 percent of all dollars paid.

1.5 percent of all claims (2.4 percent of perinatal claims) have PTL ratios $>1$. Surprisingly, 101 of these claims were resolved with primary carriers' money alone, meaning that insurance carriers paid more than the limits. They may have done so to 

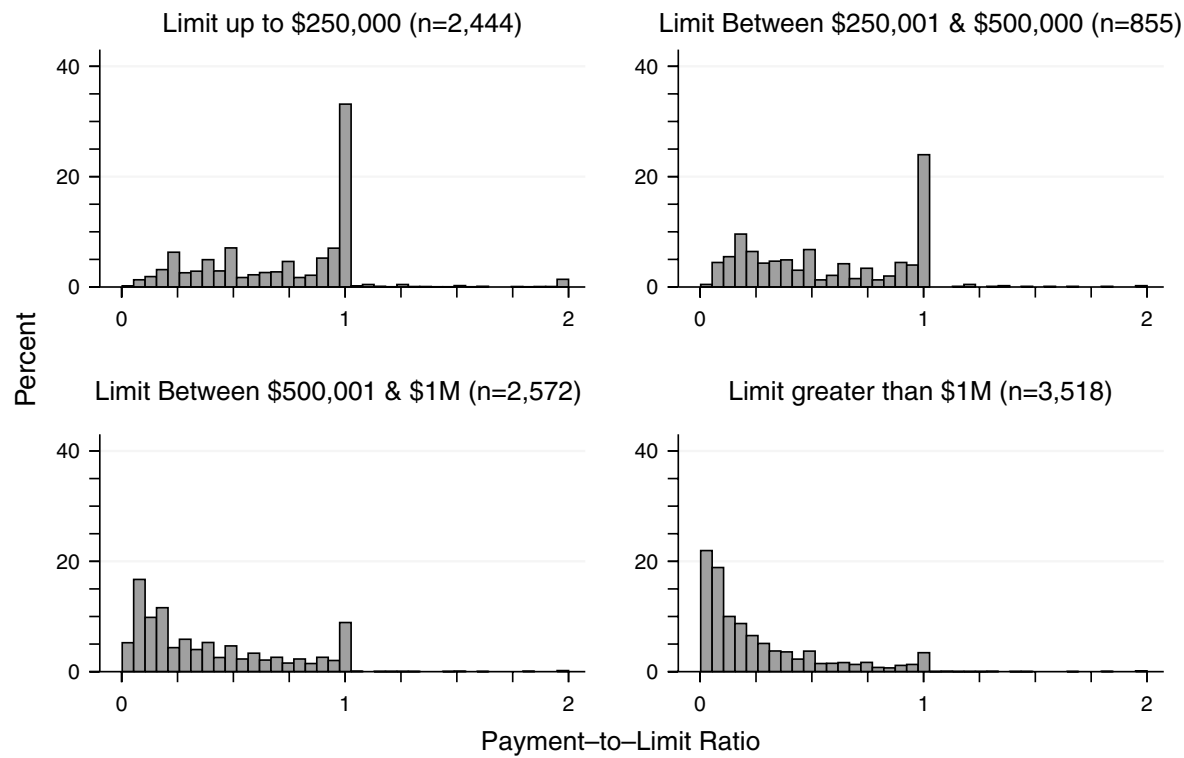

Figure 3. Distributions of payment-to-limit ratios by policy size. Distributions of payment-to-limit ratios for various ranges of real policy limits measured in the closing year for all claims and for perinatal claims against physicians covered by medical malpractice policies (measured in 2003 dollars) and closed from 1990 to 2003 with payout $>\$ 25,000$ in 1988 dollars, excluding claims with payments by excess carriers. Each bar represents a 0.05 increment. All claims with ratios greater than 2 were set equal to 2 .

Table 1 Sources of funds paid on claims, 1990-2003

\begin{tabular}{lccrrrr}
\hline $\begin{array}{l}\text { Payment by } \\
\text { primary insurer? }\end{array}$ & $\begin{array}{l}\text { Payment by } \\
\text { excess carrier? }\end{array}$ & $\begin{array}{l}\text { Payment by } \\
\text { physician } \\
\text { out-of-pocket? }\end{array}$ & $\begin{array}{c}\text { Number } \\
\text { of claims }\end{array}$ & $\begin{array}{c}\text { \% of total } \\
\text { number }\end{array}$ & $\begin{array}{c}\text { Total dollars paid } \\
\text { in millions of } \\
\text { 2003 dollars) }\end{array}$ & $\begin{array}{c}\text { of total } \\
\text { dollars }\end{array}$ \\
\hline Y & $\mathrm{N}$ & $\mathrm{N}$ & $9,322^{\mathrm{a}}$ & 97.87 & $\$ 2,438$ & 94.95 \\
$\mathrm{Y}$ & $\mathrm{Y}$ & $\mathrm{N}$ & 128 & 1.34 & $\$ 89$ & 3.46 \\
$\mathrm{Y}$ & $\mathrm{N}$ & $\mathrm{Y}$ & 55 & 0.58 & $\$ 29$ & 1.12 \\
Y & $\mathrm{Y}$ & $\mathrm{Y}$ & 7 & 0.07 & $\$ 11$ & 0.43 \\
Other b & & & 13 & 0.14 & $\$ 1$ & 0.04 \\
Total & & & 9,525 & 100.00 & $\$ 2,568$ & 100.00 \\
\hline
\end{tabular}

${ }^{\text {a}}$ Deductibles paid in 263 cases.

${ }^{\mathrm{b}}$ Includes claims paid using only physician deductible $(n=12)$ or excess carrier funds and physician deductible $(n=1)$.

protect themselves against bad faith refusal-to-settle claims by insured physicians or to avoid future defense costs. Payments above the limits from any source are more common when policies are small, occurring in 3.7 percent of the cases with real coverage measured in the closing year $\leqslant \$ 250,000$, vs. 0.7 percent of cases with real 
coverage of $\$ 500,000$ or more (difference significant at the 1 percent level). The inverse relationship between policy size and frequency of payments above the limits probably reflects the underlying distribution of injuries (i.e., fewer injuries result in damages that exceed larger policies).

Physician out-of-pocket payments appear in 0.65 percent of the reports (an average of four such payments per year), with no apparent trend in frequency. Of 62 total outof-pocket payments, 38 were $\$ 100,000$ or less, 14 were $\$ 100,001-300,000,10$ were $\$ 300,001$ or more, all in 2003 dollars. The real mean (median) was $\$ 190,000(\$ 54,000)$ for all claims. No significant time trend in real payment size was detected (Cuzick's non-parametric test for trend across ordered groups ${ }^{15}$ produced a $z$ of $\left.0.51(P=0.61)\right)$. In 18 of the 62 cases in which physicians made out-of-pocket payments, primary insurers paid less than the reported policy limits. Possible explanations for this pattern include eroded primary limits, coverage disputes, prior physician refusal to settle, or patients' insistence on personal contributions from physicians.

As one might expect, the likelihood of an out-of-pocket payment decreased as insurance coverage increased. Out-of-pocket payments appeared most often when real coverage was $\$ 250,000$ or less, occurring in 1.3 percent of the cases $(32$ of 2,488$)$. With policies larger than $\$ 500,000$, the frequency dropped to 0.4 percent $(23$ of 6,160$)$. It is important to remember that these estimates reflect the experience of physicians with paid claims, not the ex ante risks faced by all physicians with policies of a given size.

Out-of-pocket payments were both more common and larger in perinatal cases, which account for 11 percent of reported payments but for 26 percent of out-of-pocket payments (16 of 62). In a logistic regression that controlled for policy size and payment size, however, the difference in the likelihood of out-of-pocket payments in perinatal and non-perinatal cases was not statistically significant (odds ratio $=0.84 ; 95$ percent $\mathrm{CI}=[0.19,3.71])$. The small number of out-of-pocket payments, which limits the test's power to detect a difference, may account for this. The real mean (median) out-ofpocket payment for perinatal claims was $\$ 270,000$ (\$120,000) compared to $\$ 160,000$ $(\$ 40,000)$ for non-perinatal claims (test of differences has insufficient power due to small number of out-of-pocket payments).

\section{Coverage purchases}

Because PTL ratios and the frequency of out-of-pocket payments vary with policy size, it is important to know how much coverage physicians purchase. Our data set (for claims closed from 1990 to 2003) includes claims on policies sold as early as 1965 but provides reasonably complete data only on policies purchased from 1988 through 1999, due to the lag between the filing date and the claim closing date. Table 2 provides distributions of policies purchased by per occurrence limit (in nominal dollars) and purchase year.

The conventional wisdom posits that most physicians buy medical malpractice policies with $\$ 1$ million (nominal) per occurrence limits. For all years in our data set,

\footnotetext{
${ }^{15}$ Cuzick (1985).
} 
Table 2 Distribution of policies purchased by per occurrence limit and purchase year (in nominal dollars)

\begin{tabular}{lccccccc}
\hline & \multicolumn{5}{c}{ Per occurrence limits (nominal) } \\
\cline { 2 - 7 } $\begin{array}{l}\text { Purchase } \\
\text { year }\end{array}$ & $\begin{array}{c}\text { Number of policies } \\
\text { purchased }^{\text {a }}\end{array}$ & $\begin{array}{c}\$ 100 K \\
(\%)\end{array}$ & $\begin{array}{c}\$ 200 K \\
(\%)\end{array}$ & $\begin{array}{c}\$ 500 K \\
(\%)\end{array}$ & $\begin{array}{c}\$ 1 M \\
(\%)\end{array}$ & $\begin{array}{c}\$ 2 M \\
(\%)\end{array}$ & $\begin{array}{c}\text { Total } \\
(\%)\end{array}$ \\
\hline 1988 & 409 & 11 & 15 & 25 & 37 & 4 & $92^{\mathrm{b}}$ \\
1989 & 567 & 11 & 25 & 29 & 24 & 1 & 91 \\
1990 & 520 & 11 & 23 & 30 & 24 & 3 & 90 \\
1991 & 608 & 12 & 23 & 30 & 24 & 2 & 91 \\
1992 & 630 & 10 & 23 & 29 & 27 & 4 & 92 \\
1993 & 688 & 10 & 24 & 24 & 30 & 3 & 91 \\
1994 & 633 & 6 & 27 & 23 & 33 & 4 & 93 \\
1995 & 634 & 4 & 25 & 22 & 35 & 5 & 91 \\
1996 & 580 & 6 & 25 & 22 & 35 & 3 & 90 \\
1997 & 631 & 6 & 22 & 21 & 41 & 2 & 92 \\
1998 & 656 & 4 & 27 & 21 & 41 & 4 & 96 \\
1999 & 600 & 8 & 24 & 25 & 31 & 3 & 92 \\
$1988-1999$ & 7,156 & & 24 & 28 & 28 & 2 \\
\hline
\end{tabular}

${ }^{a}$ In each row, the total includes all policies purchased that year, including policies with limits other than those shown. On average across purchase years, 0.1 percent of policies purchased had limits of less than $\$ 100 \mathrm{~K}, 0$ percent between $\$ 100 \mathrm{~K}$ and $\$ 200 \mathrm{~K}, 2$ percent between $\$ 200 \mathrm{~K}$ and $\$ 500 \mathrm{~K}, 3$ percent between $\$ 500 \mathrm{~K}$ and $\$ 1$ million, 1 percent between $\$ 1$ million and \$2 million, and 2 percent above \$2 million.

${ }^{\mathrm{b}}$ These totals do not sum to 100 percent because not all policy sizes are included.

however, only 31 percent of the reports indicated policies with $\$ 1$ million limits, while 32 percent indicated nominal limits of $\$ 200,000$ or less. The median nominal policy limit for all claims was $\$ 500,000$ and was constant during our sample period.

Figure 4 displays trends in real coverage amounts by year of purchase, separating perinatal physicians from non-perinatal physicians. For both groups, from 1988 to 1999 mean and median nominal policy limits purchased were stable in nominal dollars but fell by roughly 30 percent in real dollars (Cuzick's non-parametric test for trend across ordered groups on purchases in real dollars produced a $z$ of $-7.09(P<0.001)$ for perinatal and $-12.70(P<0.001)$ for non-perinatal physicians).

In most purchase years analyzed, mean limits were smaller for perinatal than for non-perinatal physicians. Because median policy size for both groups generally is the same across years, the lower mean for perinatal physicians must reflect fewer perinatal policies with high limits. In fact, 25 percent of perinatal claims involved policies with nominal limits $\geqslant \$ 1$ million vs. 39 percent of claims involving non-perinatal physicians (difference $=14$ percent; a $t$-test indicates a 95 percent $\mathrm{CI}=[9.8$ percent, 16.9 percent $]$ ). Perinatal physicians carried smaller policies even though their payouts were larger on average. Given the higher payouts and smaller average policy limits associated with perinatal claims, it follows that the mean PTL ratios for perinatal claims will be higher than in non-perinatal claims. Excluding claims with excess carrier payments, the average PTL ratio was 67 percent in perinatal cases vs. 45 percent in non-perinatal cases (difference $=22$ percent; a $t$-test indicates a 95 percent $\mathrm{CI}=[18.6$ percent, 25.6 percent]). 


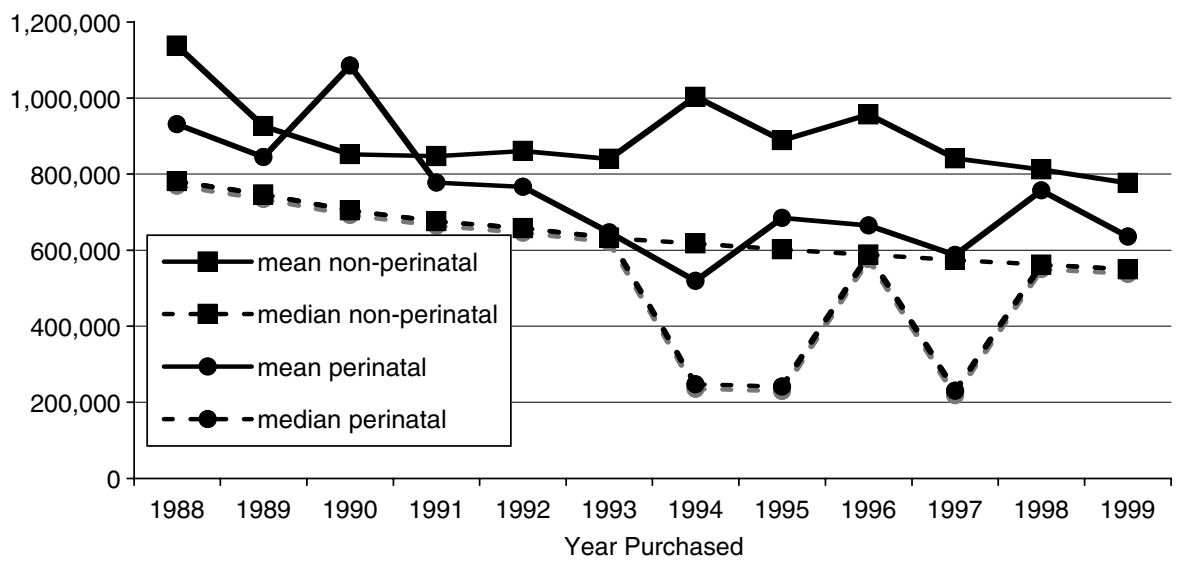

Figure 4. Trends in mean and median purchased policies (measured in 2003 dollars). Trends in mean and median purchased policies measured in 2003 dollars in the purchase year for perinatal claims and nonperinatal claims against physicians and closed from 1990 to 2003 with payout $>\$ 25,000$ in 1988 dollars.

\section{Claim rates and payments}

Table 3 presents trends in the number of large paid claims. The number of paid claims was stable per million Texas residents (OLS regression of number of claims on year produces coefficient on year $=-0.3 ; 95$ percent $\mathrm{CI}=[-0.7,0.2]$ ), but showed a statistically significant decline, at the 5 percent level, per 1,000 non-federal practicing Texas physicians (coefficient on year $=-0.5$; 95 percent $C I=[-0.8,-0.2]$ ) and per $\$ 1$ billion in Texas health care spending (coefficient on year $=-0.65 ; 95$ percent $\mathrm{CI}=[-0.79,-0.51])$.

Payments were also fairly stable, as shown in Table 3. For non-perinatal cases, the mean real payment per claim dropped from $\$ 303,000$ in 1990 to $\$ 253,000$ in 2003 , but the median increased from $\$ 141,000$ to $\$ 187,000$. This suggests that over time relatively fewer extremely large payments were made but, at the same time, there were relatively fewer smaller payments. Payments exceeding \$1 million (2003\$) comprised 6.5 percent of the claims in 1990 compared with 2.5 percent in 2003. Similarly, total payments of less than $\$ 100,000$ (2003\$) comprised 35 percent of the claims in 1990 compared with 31 percent in 2003. Perinatal claims saw decreases in both the mean and median real payment.

Plaintiff jury verdicts were present in a small portion of closed claims $(n=189 ; 1.98$ percent of all paid claims). The mean (median) real verdict was $\$ 2,410,000$ (\$640,000); the mean (median) real payout after verdict was $\$ 760,000(\$ 400,000)$. No significant trend over time in verdicts (adjusted for inflation) was detected (Cuzick's nonparametric test for trend across ordered groups produced a $z$ of $-0.977(P=0.33)){ }^{16}$

${ }^{16}$ Hyman et al. (2007) provide a detailed analysis of claims closed after jury verdicts. 
Table 3 Trends in number of claims adjusted for population, physician population, medical expenditures and total payment summary statistics by closing year (in thousands of 2003 dollars)

\begin{tabular}{|c|c|c|c|c|c|c|c|c|c|}
\hline \multirow{2}{*}{$\begin{array}{l}\text { Closing } \\
\text { year }\end{array}$} & \multirow{2}{*}{$\begin{array}{l}\text { Number of paid } \\
\text { claims per } \\
\text { 1,000,000 } T X \\
\text { residents }\end{array}$} & \multirow{2}{*}{$\begin{array}{c}\text { Number of paid } \\
\text { claims per } \\
\text { 1,000 TX } \\
\text { physicians }\end{array}$} & \multirow{2}{*}{$\begin{array}{c}\text { Number of paid } \\
\text { claims per } \$ 1 \text { billion } \\
\text { in personal } \\
\text { medical } \\
\text { expenditures }\end{array}$} & \multicolumn{2}{|c|}{ All claims } & \multicolumn{2}{|c|}{ Perinatal claims } & \multicolumn{2}{|c|}{ Non-perinatal claims } \\
\hline & & & & $\begin{array}{l}\text { Mean total } \\
\text { payment }\end{array}$ & $\begin{array}{c}\text { Median total } \\
\text { payment }\end{array}$ & $\begin{array}{c}\text { Mean total } \\
\text { payment }\end{array}$ & $\begin{array}{c}\text { Median total } \\
\text { payment }\end{array}$ & $\begin{array}{c}\text { Mean total } \\
\text { payment }\end{array}$ & $\begin{array}{c}\text { Median total } \\
\text { payment }\end{array}$ \\
\hline 1990 & 36 & 27 & 16 & 325 & 141 & 481 & 264 & 303 & 141 \\
\hline 1992 & 42 & 32 & 16 & 293 & 145 & 404 & 263 & 271 & 132 \\
\hline 1993 & 36 & 28 & 13 & 266 & 159 & 437 & 253 & 242 & 158 \\
\hline 1994 & 34 & 25 & 12 & 290 & 167 & 406 & 247 & 275 & 154 \\
\hline 1995 & 38 & 28 & 13 & 247 & 151 & 432 & 241 & 225 & 133 \\
\hline 1996 & 34 & 25 & 11 & 276 & 160 & 368 & 209 & 266 & 153 \\
\hline 1997 & 37 & 26 & 11 & 250 & 158 & 294 & 221 & 245 & 144 \\
\hline 1998 & 31 & 22 & 9 & 249 & 162 & 215 & 208 & 253 & 151 \\
\hline 1999 & 35 & 23 & 10 & 275 & 166 & 403 & 218 & 261 & 165 \\
\hline 2001 & 34 & 22 & 9 & 268 & 182 & 303 & 208 & 264 & 177 \\
\hline 2002 & 30 & 20 & 7 & 269 & 184 & 307 & 204 & 265 & 176 \\
\hline 2003 & 36 & 23 & 8 & 258 & 195 & 318 & 200 & 253 & 187 \\
\hline
\end{tabular}

Trends in number of adjusted claims and summary statistics for total payments measured in 2003 dollars for perinatal, non-perinatal, and all claims with payout $>\$ 25,000$ in 1988 dollars. 
Using Texas State Data Center and Office of the State Demographer data on countylevel variation in urbanization, we found no substantial differences between urban and rural counties in PTL ratios, policy purchases, or payment size trends (data and details available from authors upon request).

\section{Discussion}

We report three central findings. First, payments on medical malpractice claims stacked up at the policy limits, especially when physicians carried smaller policies, and payments above the limits were rare. Second, physician out-of-pocket payments were uncommon. Third, both non-perinatal and perinatal physicians bought considerably less real coverage over time. The decline corresponded with lower average payments on perinatal claims, and may have contributed to it. We are able to report these findings only because Texas mandates a data collection system to track insurance and liability system activity. Having such systems in all states would facilitate the study of the malpractice system and greatly advance the policy debate. ${ }^{17}$

The spike in payouts at the policy limits likely includes many claims with higher values that were negotiated downward. In these cases, patients received less compensation than their claims warranted. Hyman et al. ${ }^{18}$ report that patients who prevail at trial often settle for the policy limits and recover less (often much less) than juries award. The spike may also include some claims that insurers overpaid because physicians pressured them to settle, because insurers wanted to limit defense costs, or because insurers sought to avoid lawsuits by physicians asserting bad faith refusal to settle claims. ${ }^{19}$

At prevailing insurance levels, physicians' personal assets seem secure. Ignoring deductibles, primary and excess carriers provided over 99 percent of dollars paid to claimants; out-of-pocket payments were few. Policy limits seem to act as de facto caps on malpractice recoveries, even when plaintiffs' damages exceed the limits. In the debate over statutory caps, these informal caps are rarely given their due. If policy limits essentially cap amounts collectible by claimants, statutory caps set above prevailing limits will have less impact on payments and premiums than one might predict. $^{20}$

Why are out-of-pocket payments so uncommon? Several reasons may account for this. First, it is costly to collect judgments from physicians personally and the economics of plaintiffs' attorneys' practices may pressure them to settle for readily available insurance dollars. ${ }^{21}$ Second, demands for out-of-pocket payments may delay the receipt of dollars insurers offer within the limits, because insurers will not settle without obtaining releases for their insureds. Third, many physicians have limited

\footnotetext{
${ }^{17}$ Sage (2004).

${ }^{18}$ Hyman et al. (2007).

${ }^{19}$ Syverud (1990).

${ }^{20}$ The impact of the damages caps Texas enacted in 2003 is studied in Hyman et al. (2008).

${ }^{21}$ Gilles (2006); Baker (2001).
} 
assets or use asset protection strategies to insulate their wealth. ${ }^{22}$ Fourth, plaintiffs' attorneys may adhere to a professional norm that makes defendants' personal assets fair game only when defendants commit especially heinous acts or intentionally underinsure. Interviews confirm that plaintiffs' lawyers seek personal assets rarely. ${ }^{23}$

Although our results will enlighten policymakers who wish to understand the connection between insurance markets and the malpractice liability system, they are subject to important limitations. First, our data set contains reports of insurance policies relating only to paid claims, which may not constitute a representative sample of all insurance policies in effect in a given year. Further study is required to determine whether the purchasing habits of physicians with paid claims differ from those of other physicians. Second, we lack data on physician specialty, so we have limited ability to identify differences in insuring patterns, out-of-pocket payments, or other matters across practice areas. Third, although Texas is the second largest state in terms of population, and third largest state in spending on health care, it is only one state. Doctors' insuring habits, the frequency of settlements above the policy limits and the number of out-of-pocket payments may differ across states. That said, the practice of settling for insurance money appears to be common across jurisdictions. Many commentators refer to it, ${ }^{24}$ and an unpublished examination of Florida closed claims revealed a spike in settlements at the policy limits. ${ }^{25}$

Our data do not explain physicians' insurance purchasing decisions. We also have not explained why real coverage levels declined over time. Physicians may take guidance from other physicians, hospitals, managed care organizations, brokers, medical societies, or financial advisors. They may have purchased less real coverage because they needed less insurance (owing to tort reforms or improvements in patient safety), because the cost of insurance increased, or because they sought to drive down payments on claims by making less insurance money available to malpractice plaintiffs. These factors may affect perinatal physicians and other physicians to different degrees, contributing to the differences we observed between the groups. Additional work is needed to explain our findings and to assess their implications for efforts to improve patient safety and to ensure that injured patients receive appropriate compensation while avoiding waste in the tort system.

\section{Glossary}

Claim:

Claims-made policy:

Closed claim: request by an insured for indemnification by an insurance company for loss incurred from an insured peril an insurance policy that covers claims made during the coverage year

a claim that has been reported to TDI as having been settled or otherwise disposed of, with all indemnity and expense payments having been made

\footnotetext{
${ }^{22}$ Stark and Gilman (2005); Tolkoff (2006).

23 Baker (2001).

${ }^{24}$ For discussions, see Baker (2001); Rice (2003); Silver and Syverud (1995).

${ }^{25}$ Watanabe (undated and unpublished).
} 
Excess policy:

a policy purchased by a physician from an excess carrier to cover amounts in excess of primary policy limits

Occurrence policy: $\quad$ an insurance policy that covers claims for harm stemming from services rendered during a coverage year

Out-of-pocket payment: a payment (other than a deductible payment) made by an insured physician to resolve a claim

Purchase year: the year during which the policy was purchased by a physician. We imputed purchase years using injury date, claim date, and type of policy. For claims-made policies, which cover claims made during a coverage year, we set the purchase year as the year a claim was reported $(5,911$ claims). For occurrence polices, which cover claims for harm stemming from services rendered during a coverage year, we set the purchase year to the year an injury occurred $(3,614$ claims).

\section{References}

American Medical Association (2005) 'Liability Insurance Requirements', from http://www.ama-assn.org/ ama/pub/category/4544.html, accessed 15 December 2006.

Avraham, R. (2006) Database of state tort law reforms, Northwestern Law \& Economics Research Paper No. 902711, from http://ssrn.com/abstract $=902711$, accessed 15 December 2006 .

Baker, T. (2001) 'Blood money, new money and the moral economy of tort law in action', Law \& Society Review 35: 275-319.

Black, B., Silver, C., Hyman, D.A. and Sage, W.M. (2005) 'Stability not crisis: Medical malpractice claim outcomes in Texas, 1998-2002', Journal of Empirical Legal Studies 2: 207-259.

Cheney, F.W. (1999) 'How much professional liability coverage is enough? Lessons from the ASA closed claims project', ASA Newsletter 63(6): 19-21.

Conrad, D.A., Whitney, C., Milgrom, P., O’Hara, D., Ammons, R., Fiset, L. and Vesneski, W. (1995) 'Malpractice premiums in 1992: Results of a national survey of dentists', Journal of the American Dental Association 126: 1045-1056.

Cuzick, J. (1985) 'A Wilcoxon-type test for trend', Statistics in Medicine 4: 87-89.

General Accounting Office (2003) Medical malpractice insurance: Multiple factors have contributed to increased premium rates, Report to Congressional Requesters, GAO, Washington, DC, June, Fig. 16.

Gilles, S.G. (2006) 'The judgment-proof society', Washington and Lee Law Review 63: 603-715.

Hyman, D.H., Black, B., Zeiler, K., Silver, C. and Sage, W.M. (2007) 'Do defendants pay what juries award?: Post-verdict haircuts in Texas medical malpractice cases, 1988-2003', Journal of Empirical Legal Studies 4: 3-68.

Hyman, D.H., Black, B., Silver, C. and Sage, W.M. (2008) 'Estimating the Effect of Damage Caps in Medical Malpractice Cases: Evidence from Texas', Journal of Legal Analysis (forthcoming).

Jenkins, J. (2003) 'Finding the truth: The medical malpractice crisis in North Carolina', North Carolina Medical Journal 64: 169-175.

King, G., Tomz, M. and Wittenberg, J. (2000) 'Making the most of statistical analyses: Improving interpretation and presentation', American Journal of Political Science 44: 347-361.

Lawthers, A.G., Localio, A.R., Laird, N.M., Lipsitz, S., Hebert, L. and Brennan, T.A. (1992) 'Physicians' perceptions of the risk of being sued', Journal of Health Politics, Policy and Law 17: 463-482.

Lowes, R. (2003) 'Protect your assets before you're sued', Medical Economics (21 February): 80-82.

Milgrom, P.M., Fiset, L., Whitney, C., Conrad, D., Cullen, T. and O'Hara, D. (1994) 'Malpractice claims during 1988-1992: A national survey of dentists', Journal of the American Dental Association 125: $462-469$. 
Milgrom, P.M., Whitney, C., Conrad, D., Fiset, L. and O'Hara, D. (1995) 'Tort reform and malpractice liability insurance', Medical Care 33: 755-764.

O'Hara, D.J., Conrad, D.A., Milgrom, P., Fiset, L. and Whitney, C. (1994) 'Dental malpractice liability insurance market: Surveys of insurers and insurance commissioners', Journal of the American Dental Association 125: 1385-1390.

Quinn, R. (1998) 'Medical malpractice insurance: The reputation effect and defensive medicine', Journal of Risk and Insurance 65: 467-484.

Rice, B. (2003) 'Could a malpractice mega-verdict wipe you out?' Medical Economics (23 May): 80-89.

Rice, B. (2005) 'Malpractice: If you're the deepest pocket', Medical Economics, from http://www.memag. $\mathrm{com} / \mathrm{memag} /$ Young + Doctors $\% 27$ + Resource + Center $\% 3 \mathrm{~A}+$ Malpractice $\% 3 \mathrm{~A}+$ Awards $\% 2$ Fsettlements/ Malpractice-If-youre-the-deepest-pocket/ArticleStandard/Article/detail/177210, accessed 20 November 2007.

Rice, B. (2006) '10 years in legal hell', Medical Economics, from http://www.memag.com/memag/article/ articleDetail.jsp?id=329107, accessed 20 November 2007.

Sage, W.M. (2004) 'The forgotten third: Liability insurance and the medical malpractice crisis', Health Affairs 23(4): 10-21.

Silver, C. and Syverud, K.D. (1995) 'The professional responsibilities of insurance defense lawyers', Duke Law Journal 45: 255-363.

Stark, B. and Gilman, P.A. (2005) 'Basics of asset protection', Journal of Medical Practice Management 20: 207-209.

Syverud, K.D. (1990) 'The duty to settle', Virginia Law Review 76: 1113-1209.

Tolkoff, M. (2006) 'Asset protection: What to do, how to do it', Medical Economics, from http:// www.memag.com $/ \mathrm{memag} /$ article/articleDetail.jsp?id = 329103\&searchString $=$ asset $\% 20$ protect, accessed 20 November 2007.

Tomz, M., Wittenberg, J. and King, G. (2001) 'CLARIFY: Software for interpreting and presenting statistical results Version 2.0', from http://gking.harvard.edu, accessed 15 December 2006.

Watanabe, Y. (undated and unpublished) 'Payment-to-limit ratio distribution of Florida closed medical malpractice claims.

\section{About the Authors}

Charles Silver holds the Roy W. and Eugenia C. McDonald Endowed Chair in Civil Procedure and is Co-Director of the Center on Lawyers, Civil Justice, and the Media at the University of Texas School of Law. He obtained a B.A. in political science from the University of Florida and an M.A. in the same subject from the University of Chicago in 1982. From 1982 to 1984, he served as the Managing Editor of Ethics. He graduated from the Yale Law School in 1987 and joined the Texas faculty later that year. He has published widely on class actions and complex lawsuits, attorneys' fees, the professional responsibilities of lawyers, insurance, and health care law and policy. Professor Silver currently serves as Associate Reporter on the American Law Institute's project on aggregate litigation.

Kathryn Zeiler is a Professor of Law at the Georgetown University Law Center. She obtained a B.S. in business from Indiana University in 1991, an M.S. in Taxation from Golden Gate University in 1995, an M.S. in social sciences from Caltech in 2000, a J.D. from the University of Southern California in 2000, and a Ph.D. in economics from the California Institute of Technology in 2003. She joined the Georgetown faculty in 2003 and has held visiting professorships at New York University School of Law and Harvard Law School. She has published articles in law reviews and peerreviewed economics and insurance journals on topics including medical malpractice, tort reform, disclosure law, empirical health law, and experimental economics. 
Bernard S. Black is Hayden W. Head Regents Chair for Faculty Excellence at University of Texas Law School, Professor of Finance at University of Texas, McCombs School of Business, Co-Director of the Center for Law, Business and Economics at the University of Texas, and managing director of the Social Science Research Network and its sub-network, the Legal Scholarship Network, and founding chairman of the annual Conference on Empirical Legal Studies. Professor Black received his B.A. from Princeton University, M.A. in physics from University of California at Berkeley and J.D. from Stanford Law School. He has also been Professor of Law at Stanford Law School (1998-2004) and Columbia Law School (1988-1998). He has published several books and numerous articles in law, finance and economics journals, principally in the areas of law and finance, corporate and securities law, international corporate governance, and corporate acquisitions. His books include The Law and Finance of Corporate Acquisitions (2nd edn., with Ronald Gilson, 1995 and supplement 2003) and Guide to the Russian Law on Joint Stock Companies (with Reinier Kraakman and Anna Tarassova (1998)).

David A. Hyman is Professor of Law and Medicine at the University of Illinois. He teaches health care regulation, civil procedure, insurance law, law and economics, professional responsibility, and tax policy. He has published articles on a wide variety of issues, but focuses his research on the regulation and financing of health care. While serving as Special Counsel to the Federal Trade Commission, Professor Hyman was principal author and project leader for the first joint report ever issued by the Federal Trade Commission and Department of Justice, titled "Improving Health Care: A Dose of Competition." $\mathrm{He}$ is also the author of Medicare Meets Mephistopheles. Professor Hyman has a B.A. (1983), J.D. (1989), and M.D. (1991) from the University of Chicago.

William M. Sage is Vice Provost for Health Affairs and James R. Dougherty Chair for Faculty Excellence in Law at the University of Texas at Austin, where he teaches courses in health law, antitrust, regulatory theory, and the professions. Professor Sage has published more than 50 articles in a variety of legal, health policy, and clinical journals. He is an elected fellow of the Hastings Center on bioethics, a recipient of an Investigator Award in Health Policy Research from the Robert Wood Johnson Foundation, and a member of the editorial board of Health Affairs. Professor Sage received his A.B. from Harvard College in 1982 and his medical and law degrees from Stanford University in 1988. He completed an internship at Mercy Hospital and Medical Center in San Diego, and served as a resident in anesthesiology and critical care medicine at the Johns Hopkins Hospital. Prior to joining the Columbia faculty in 1995, Professor Sage practiced corporate and securities law at O'Melveny \& Myers in Los Angeles and, in 1993, headed four working groups of the White House Task Force on Health Care Reform. 